\title{
Heavy metal contamination of topsoil and parts of peach-tree growing at different distances from a smelting complex
}

\author{
M. D. Dimitrijević ${ }^{1}$ M. M. Nujkić1 ${ }^{1}$ S. Č. Alagić $^{1} \cdot$ S. M. Milić ${ }^{1}$ S. B. Tošić ${ }^{2}$
}

Received: 26 March 2015/Revised: 15 September 2015/Accepted: 7 October 2015/Published online: 2 November 2015

(C) Islamic Azad University (IAU) 2015

\begin{abstract}
This paper reports on the content of six heavy metals $(\mathrm{Cu}, \mathrm{Zn}, \mathrm{Pb}, \mathrm{As}, \mathrm{Cd}$ and $\mathrm{Ni})$ in topsoil and parts of peach-tree, sampled from eight locations in urban-industrial and rural areas located at various distances from the Bor copper smelter, Serbia. Topsoil samples were analyzed for physical and chemical properties, while the content of heavy metals in all samples was determined using an inductively coupled plasma optical emission spectrometer (iCAP 6000). The enrichment factor showed that the topsoil was enriched by heavy metals (except for nickel), at all locations. An extreme enrichment by copper was found at six locations $\left(\mathrm{EF}_{\mathrm{soil}}=86-101\right)$. The enrichment factors of heavy metals in peach-tree parts were highest in roots and leaves. The most extreme enrichment by copper was found to occur in the roots $\left(\mathrm{EF}_{\text {plant }}=68.80\right)$ from the flotation tailing pond. Among the studied heavy metals, only the content of zinc was within normal limits for plants. Calculated biological concentration factors $(\mathrm{BCF}<1)$ indicated a limited soil-to-root transfer of heavy metals. Moreover, the leaf/branch ratio as well as numerous and very strong Pearson's correlations between elements in the peach-tree parts confirmed that leaves represent the best indicators of pollution originating from atmospheric deposition. Principal component analysis identified sources of heavy metals in soil and parts of peach-tree.
\end{abstract}

M. D. Dimitrijević

mdimitrijevic@tf.bor.ac.rs

1 Department of Chemical Technology, Technical Faculty in Bor, University of Belgrade, VJ 12, POB 50, Bor 19210, Serbia

2 Department of Chemistry, Faculty of Sciences and Mathematics, University of Nis, Višegradska 33, Niš 18000, Serbia
Keywords Toxic elements · Enrichment factor - Prunus persica $\cdot$ Pollution

\section{Introduction}

Metal extraction, i.e., mining, mineral processing and smelting, generates various waste materials (waste rocks, mill and flotation tailings, smelting slag, waste solutions, flue gases and dust) (Moore and Louma 1990; Stüben et al. 2001; Bianchini et al. 2015). These waste materials pollute soil, surface and underground water, as well as air even far from the source of pollution ( $\mathrm{Li}$ et al. 2006; Malmstrom et al. 2006; Anju and Banerjee 2012).

Toxic metals are usually accumulated in topsoil and can enter the food chain through plants. These metals contaminate the environment by affecting soil properties, biomass and crop yields, and ultimately human health (Mudgal et al. 2010). Toxicity of the heavy metals (HMs) that are absorbed by vegetation or retained in the soil depends on their concentration, type of metallic compound present in the soil and bioavailability, which in turn depends on the $\mathrm{pH}$ of the soil and the content of the organic matter (Alvarez et al. 2003).

It can be said that plants represent important components of ecosystems as they can transfer elements (including toxic metals) from abiotic to biotic environments (Chojnacka et al. 2005). Generally, HMs such as Cd, Pb, $\mathrm{Hg}$ and As are phytotoxic at extremely low concentrations (metalloid As is often included in HM category due to its toxic potential). The essential metals such as the micronutrients $\mathrm{Cu}, \mathrm{Zn}, \mathrm{Ni}$ and $\mathrm{Fe}$ service certain biochemical and physiological functions in plants, but they are also phytotoxic above certain threshold levels (Nagajyoti et al. 2010; Ayari et al. 2010; Alagić et al. 2015). 
Numerous investigations have confirmed that some plants grow successfully even in the soil that is heavily polluted by heavy metals. HM concentrations in these plants are often considerably elevated due to their high ability to absorb them from soil, water or air (Alvarez et al. 2003; Gonzalez and Gonzalez-Chavez 2006; Li and Yang 2008; Arnetoli et al. 2008; Tian et al. 2009; Agyarko et al. 2010; Mudgal et al. 2010; Antonijević et al. 2012). Usually, these are wild-growing species, which have developed successful strategies for HM tolerance. Therefore, plants with high tolerance to HMs are the subject of intensive research in terms of their use for phytoremediation and biomonitoring around mineral-ore mines and smelters (Gonzalez and Gonzalez-Chavez 2006; Mingorance et al. 2007; Antonijević et al. 2008; Rashed 2010; Ashraf et al. 2011; Balabanova et al. 2012; Mehes-Smith et al. 2013; Saba et al. 2015).

More than 100 years of the mining and smelting operations around the town of Bor (Serbia) has had a strong impact on the environment and public health. In view of the fact that Bor is situated near one of the mines and the copper smelter belonging to the Bor Mining and Smelting Complex (RTB Bor), the town represents an environmental hot spot of Serbia and Europe (Dimitrijević et al. 2009). According to the Local Environmental Action Plan (LEAP 2003), from the extraction processes in the RTB Bor complex, 5-20 kg As, 5-8 kg Zn, 6-25 kg Pb and $\geq 3.5 \mathrm{t}$ $\mathrm{SO}_{2}$ per capita are emitted each year and 11,300 $\mathrm{t}$ of waste rocks and tailings are dumped. Waste gases released from the smelter smokestacks $\left(\mathrm{SO}_{2}\right.$ and toxic elements in particulate matter such as $\mathrm{As}, \mathrm{Cd}, \mathrm{Pb}$ ) devastated agricultural soil around the town of Bor in an area of approximately 22,000 ha. Despite this gloomy picture, the town, which is exposed to this extreme pollution, is still rich in vegetation. This indicates that different plant species have adapted to the existing pollution. It is especially interesting to note that the soil surrounding the old flotation tailing pond (agricultural soil in the past), which is within the boundaries of the RTB complex and close to the smelting plant, has been overgrown by various wild-growing plant species. Among them, peach and apple trees, as well as blackberry and grapevine shrubberies can be also found. Unfortunately, these plants bear fruits that are contaminated by HMs.

Plants usually accumulate larger quantities of metals in their leaves than in their fruits or seeds. On the other hand, some studies have shown that heavy metals significantly contaminate the fruit (Matei et al. 2013; Radwan and Salama 2006). Therefore, in this paper the concentrations of heavy metals $(\mathrm{Cu}, \mathrm{Zn}, \mathrm{Pb}, \mathrm{As}, \mathrm{Cd}$ and $\mathrm{Ni})$ in peach-trees' parts (root, branch, leaf, fruit) and physical and chemical characteristics of the topsoil, in which peach-trees grow, have been determined, correlated and compared with the control site (unpolluted area). Experiments were carried out during autumn 2012 on the authentic sort of a peach-tree, Prunus persica L. Batech, which produces fruit with white pulp. The distance of the sampling sites from the copper smelter, which is considered to be the main pollution source in the Bor region, was taken into account in the analysis of the heavy metal content and statistical analysis. The obtained results are evaluated in terms of peach-trees' use for phytoremediation and biomonitoring of areas polluted by HMs produced by copper smelter activity. The risks involved with using the peach-tree fruit as food is estimated by comparing the obtained results with the recommended levels in the Serbian and European regulations.

\section{Materials and methods}

\section{Description of the sampling sites}

The municipality of Bor is located in the mountain and forest area of the central part of Eastern Serbia (area of $856 \mathrm{~km}^{2}$ ), <50 and $100 \mathrm{~km}$ far from the Bulgarian and Romanian border, respectively. The population density is 58.4 inhabitants per $\mathrm{km}^{2}$. The majority of population lives in the urban area of the town of Bor, while the remainder of the population lives in the rural zones (12 rural settlements). The geographic coordinates of Bor are: $44^{\circ} 25^{\prime} \mathrm{N}$ latitude and $22^{\circ} 06^{\prime} \mathrm{E}$ longitude. The altitude of Bor is $378 \mathrm{~m}$ above sea level, which is low compared to the surrounding tall mountains (Stol $1156 \mathrm{~m}$, Veliki Krš $1146 \mathrm{~m}$ and CrniVrh $1043 \mathrm{~m}$ ). Thus, Bor is located in the valley of the Bor River. The main industrial activities in Bor are mining and metallurgy, where one of the copper mines and the smelting complex are located on the northeastern edge of the town. The climate of the Bor area is moderately continental. The average annual values of meteorological parameters in 2012 were: air temperature $11.34{ }^{\circ} \mathrm{C}$, atmospheric pressure $971.6 \mathrm{mbar}$, relative humidity $65.75 \%$, precipitation $673.5 \mathrm{~mm} / \mathrm{m}^{2}$, wind speed $0.62 \mathrm{~m} / \mathrm{s}$ and the wind calm period $57.6 \%$. The dominant winds in this region are in the west (W), the west-northwest (WNW) and the northwest (NW) direction. Winds less frequent are in the direction of east (E), east-northeast (ENE) and east-southeast (ESE). The least frequent winds are in the direction of south (S) and south-southwest (SSW) (Fig. 1). Wind direction influences distribution of pollutants from the industrial zone to the town and surrounding areas.

In this study, the concentrations of investigated heavy metals were determined in soil and parts of P. persica $\mathrm{L}$. Batech, sampled from eight sampling sites differing in distance from the smelter smokestacks (120 and $150 \mathrm{~m}$ high), as given in Table 1. 


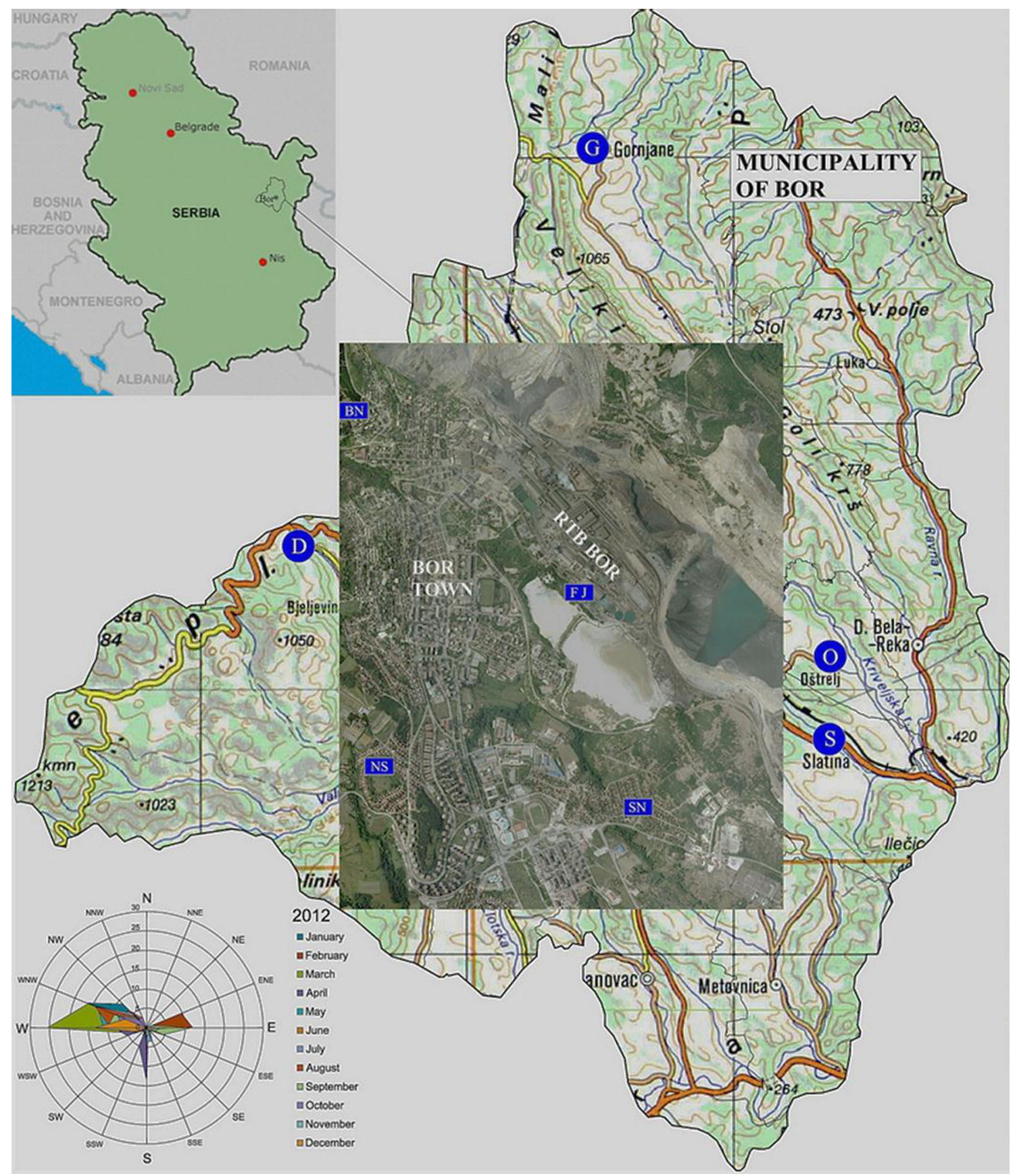

Fig. 1 Map of the study area showing measuring sites in the town of Bor and its surroundings

The selection of the representative sampling sites was based on the presence of investigated plant species primarily in the dominant wind directions from the smelting complex. The urban-industrial (UI) zone included four sampling sites as follows: the old flotation tailing pond (FJ, Flotacijsko jalovište), the hospital settlement (BN, Bolničko naselje), a part of the town which is situated near the city hospital, and the two other suburbs: the settlement "Sun" (NS, Naselje
Sunce) and Slatina settlement (SN, Slatinsko naselje). All the sites in the UI zone are located very close to the copper smelter. The rural zone (R) included three rural settlements: Oštrelj (O), Slatina (S) and Dubašnica (D). The control zone (C) was in an unpolluted area of the rural settlement Gornjane $(\mathrm{G})$ which is located $19 \mathrm{~km}$ from the town of Bor. The Gornjane area is naturally protected from pollution by the Veliki Krš mountain (Fig. 1). 
Table 1 Distance of the sampling sites from the main pollution source and dominant wind directions

\begin{tabular}{llll}
\hline Sampling site & Zone & Distance $(\mathrm{km})$ & Wind direction \\
\hline Flotation tailing pond (FJ) & UI & 0.7 & WNW, NW \\
Hospital settlement (BN) & UI & 2.2 & E, ESE \\
The settlement "Sun" (NS) & UI & 2.5 & E, ENE \\
Slatina's settlement (SN) & UI & 2.3 & WNW, NW \\
Oštrelj (O) & R & 4 & W, WNW \\
Slatina (S) & R & 7 & NW, WNW \\
Dubašnica (D) & R & 17 & E, ESE \\
Gornjane (G) & C & 19 & S \\
\hline
\end{tabular}

\section{Sample collection, preparation and analysis}

Samples of peach-tree parts (P. Persica L. Batech) together with the associated soil samples were taken from selected sites in September 2012, when the maximum HM enrichment was expected. At each site, samples of roots, branches, leaves and fruits were taken from three to five peachtrees. Leaves were taken from different quarters of the canopy (branches at a height $2.5 \mathrm{~m}$ above the soil). Soil samples were taken from the rooting zone $(0-30 \mathrm{~cm})$. Root samples were thoroughly washed with tap water followed by distilled water, whereas the aboveground plant parts remained unwashed. Each plant part and soil sample was a composite of 3-5 subsamples. All the samples were dried to a constant weight at room temperature, pulverized and passed through a 2-mm sieve for subsequent chemical analysis in triplicate. Mineralization of all samples was done according to US EPA method 3052 (USEPA 1996), as described in a previous work (Alagić et al. 2015).

Analyses were carried out using an iCAP 6000 inductively coupled plasma optical emission spectrometer (Thermo Scientific, Cambridge, UK) with an Echelle optical design and a charge injection device (CID) solidstate detector (Alagić et al. 2015). All results were calculated on a dry weight basis ( $\mathrm{mg} / \mathrm{kg} \mathrm{DW})$.

The $\mathrm{pH}$ and electrical conductivity (EC) values (solid:distilled water $=1: 2.5$ ) of the soil samples were measured using a pH meter (3510 Jenway, UK) and an EC meter (4510 Jenway, UK), respectively. The soil organic matter (OM) was determined by the loss-on-ignition (LOI) method at $550{ }^{\circ} \mathrm{C}$ (Jolivet et al. 1998).

\section{Data processing and statistical analysis}

The enrichment factor for elements in soils, $\mathrm{EF}_{\text {soil }}$, is used to assess the level of pollution and the possible anthropogenic influence. The enrichment factor (Eq. 1) is the relative abundance, with respect to iron, of one element, $[\mathrm{M}]$, in a soil compared to its relative abundance $[\mathrm{M} / \mathrm{Fe}]$ in the local control site (Oliva and Espinosa 2007):

$\mathrm{EF}_{\text {soil }}=[\mathrm{M} / \mathrm{Fe}]_{\text {soil }} /[\mathrm{M} / \mathrm{Fe}]_{\text {control }}$

In this equation, the content of metal $\mathrm{M}$ was normalized to iron. Iron was used as a metal for normalization since its anthropogenic sources are small compared to natural sources. Five contamination categories were recognized on the basis of the enrichment factor values: depletion to minimal enrichment $(\mathrm{EF}<2)$, moderate enrichment $(E F=2-5)$, significant enrichment $(E F=5-20)$, very high enrichment $(E F=20-40)$ and extremely high enrichment $(E F>40)$. As the $E F$ value increases, the contribution of the anthropogenic origin also increases (Sutherland 2000).

The enrichment factor of a plant, $\mathrm{EF}_{\text {plant }}$, was calculated using Eq. (2) (Kisku et al. 2000):

$\mathrm{EF}_{\text {plant }}=\frac{[\text { Metal }] \text { in plant parts at polluted site }}{[\text { Metal }] \text { in plant parts at unpolluted (control)site }}$

The biological concentration factor, $\mathrm{BCF}$, was calculated as the ratio of the metal concentration in roots to that in soil, as follows:

$\mathrm{BCF}=[\text { Metal }]_{\text {root }} /[\text { Metal }]_{\text {soil }}$

Values of $\mathrm{BCF}>1$ indicate the accumulation of a particular trace metal in roots (Alagić et al. 2013).

The ratios of concentrations between plant parts, $R$, were estimated using Eqs. (4)-(6) (Oliva and Mingorance 2006):

$R_{\text {leaf } / \text { branch }}=[\mathrm{M}]_{\text {leaves }} /[\mathrm{M}]_{\text {branch }}$

$R_{\text {fruit/leaf }}=[\mathrm{M}]_{\text {fruit }} /[\mathrm{M}]_{\text {leaves }}$

$R_{\text {fruit } / \text { branch }}=[\mathrm{M}]_{\text {fruit }} /[\mathrm{M}]_{\text {branch }}$

These three ratios give information concerning the different accumulation in each part and indicate whether there is a free movement of the elements between the parts. Values of $R>1$ indicate pollution via atmosphere.

Data obtained in instrumental analysis are presented as mean values including standard deviation. Pearson's correlation coefficients were used to express associations between soil and plant quantitative variables, considering two-tailed statistical significance at the $95 \%$ confidence interval. PCA was applied for the purpose of identifying the origin of HMs in soil and plant samples (Doležalová Weissmannová et al. 2015). All data were analyzed using a SPSS statistical program package (release 17.0). 


\section{Results and discussion}

\section{Soil properties and heavy metal concentrations in soil and plant parts}

The topsoil characteristics from the eight sampling sites demonstrated considerable differences in terms of $\mathrm{pH}, \mathrm{EC}$ and OM (Table 2). Soil at the site FJ is extremely acidic ( $\mathrm{pH}$ is 4.39), probably due to the weathering oxidation of pyrite in the soil, over many decades. Moreover, soil at the same site and in comparison with other sites has the highest electrical conductivity of $1371 \mu \mathrm{S} / \mathrm{cm}$ and very low content of organic matter $(6.2 \%)$. Soil at the site $\mathrm{BN}$ is strongly acidic $(\mathrm{pH}=5.22)$, while sites $\mathrm{D}$ and $\mathrm{G}$, and $\mathrm{NS}, \mathrm{SN}, \mathrm{O}$ and $\mathrm{S}$ are slightly acidic and neutral, respectively. The overall electrical conductivity of the samples at the studied sites is low since the EC values vary from 89.9 up to $176.4 \mu \mathrm{S} / \mathrm{cm}$. Conductivity in natural soil varies between 200 and $800 \mu \mathrm{S} /$ $\mathrm{cm}$, and this is necessary for the optimum plant growth (Sadhu et al. 2012). Although the content of OM varies in a wide range (5.2-21.2\%), the analyzed soil samples have a predominantly lower OM content, especially in rural areas. The soil with $21.2 \%$ of OM was sampled at the site NS which represents a border of the urban area of Bor and is located on the former agricultural soil.

The content of HMs in the analyzed soil varies within wide ranges (Table 2).

It can be seen in Table 2 that the concentrations of investigated HMs in soil decrease in the following order: $\mathrm{Cu}>\mathrm{Zn}>\mathrm{Pb}>\mathrm{As} \geq \mathrm{Ni}>\mathrm{Cd}$ (Fe was not considered, and it was used only for estimation of $\left.\mathrm{EF}_{\text {soil }}\right)$. It is clear that the soil is mostly polluted by $\mathrm{Cu}$ and except for the controlling site $(\mathrm{G})$; the range of $\mathrm{Cu}$ concentrations is $141.5-1586 \mathrm{mg} / \mathrm{kg}$. The maximum content of $\mathrm{Cu}$ is over 40 times higher than the maximum allowable concentrations (MAC) in Serbia, or 30-50 times higher than the normal values in the soil (Table 2) (Kabata-Pendias and Mukherjee 2007; Alloway 2013). Only at sites G and D, Cu concentration is lower than the MAC for agricultural soil $(150 \mathrm{mg} / \mathrm{kg})$. It should be noted that in all UI areas, soil $\mathrm{Cu}$ content is higher than $1000 \mathrm{mg} / \mathrm{kg}$ which is a direct consequence of the copper mine tailings existence in this area (Antonijević et al. 2012).

The $\mathrm{Zn}$ content in the soil is increased relative to the maximum allowable concentration (MAC) in Serbia at all UI locations, and the highest value of $465 \mathrm{mg} / \mathrm{kg}$ was recorded at site $\mathrm{SN}$, most likely due to the nearby foundry for copper and copper alloys. Furthermore, a considerably higher concentration of lead $(238.4 \mathrm{mg} / \mathrm{kg})$ when compared to the MAC in Serbia was determined location NS. This can be explained by the proximity of the main road with dense traffic as a source of lead released through

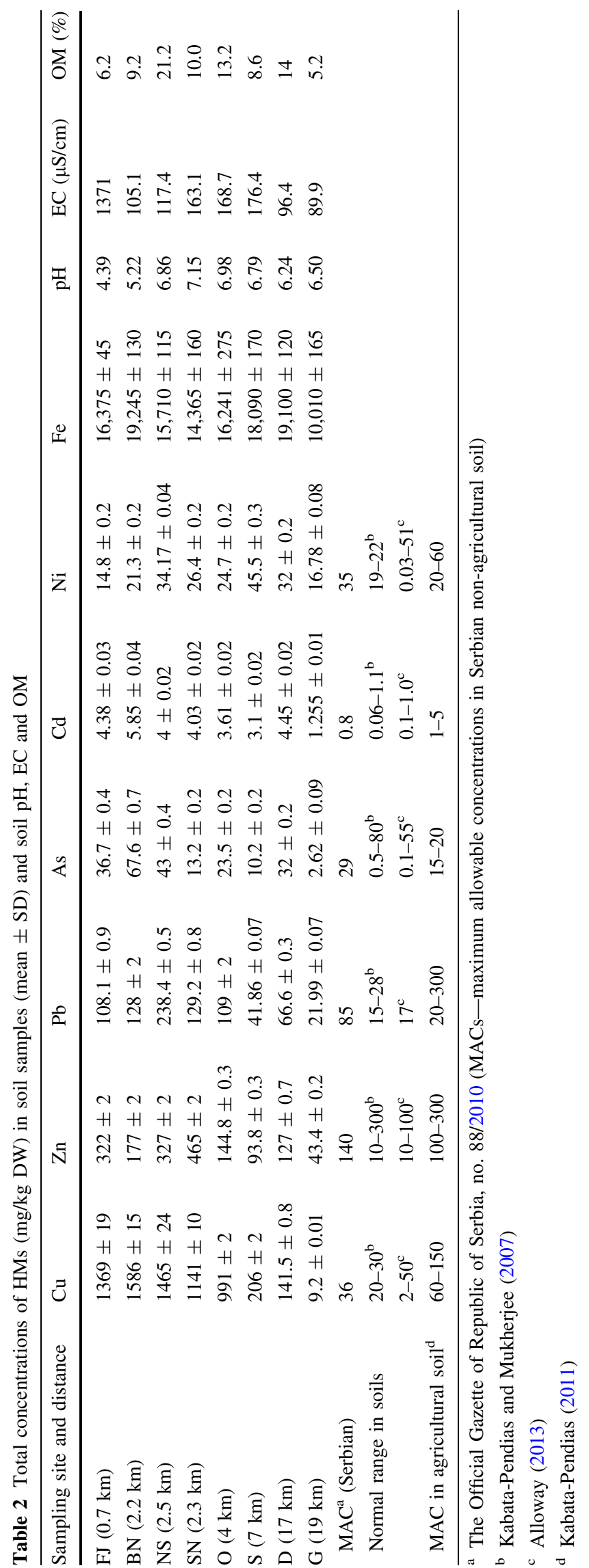


usage of leaded gasoline in the cars and trucks. A similar average concentration of $\mathrm{Pb}(202 \mathrm{mg} / \mathrm{kg})$ was determined in the urban soils of Palermo Italy (Salvagio Manta et al. 2002). The highest As concentration of $67.6 \mathrm{mg} / \mathrm{kg}$ was recorded at site $\mathrm{BN}$; some increased concentrations (higher than the MAC in Serbia) were found at sites FJ, BN, NS and D. However, all As concentrations fall into the range of normal values found in soil (Kabata-Pendias and Mukherjee 2007). Excluding the control site G, the Cd concentration is increased at all sites by $4-5$ times regarding the MAC in Serbia and normal values in soil (Kabata-Pendias and Mukherjee 2007; Alloway 2013). The highest value of $5.85 \mathrm{mg} / \mathrm{kg}$ for $\mathrm{Cd}$ was recorded at site $\mathrm{BN}$. One of the interesting findings is that the highest soil pollution by $\mathrm{Cu}, \mathrm{As}$ and $\mathrm{Cd}$ is recorded at site $\mathrm{BN}$, where the public hospital is located. This site is exposed to high concentrations of $\mathrm{SO}_{2}$ and particulate matter in wind calm periods $(\sim 60 \%)$ or under E and ESE winds $(\sim 10 \%)$ (Dimitrijević et al. 2009), essentially, during whole year, regardless of wind activity (a simple consequence of the close proximity of the main source of pollution). In addition, Ni concentration in soil at all sites, except for site $\mathrm{S}$, is lower than the MAC in Serbia $(35 \mathrm{mg} / \mathrm{kg})$.

The data in Table 2 show that the UI area is more polluted by $\mathrm{Cu}, \mathrm{Zn}$ and $\mathrm{Pb}$, than area $R$, while this trend is not observed for As, $\mathrm{Cd}$ and $\mathrm{Ni}$. This supports the conclusion that $\mathrm{Cu}, \mathrm{Zn}$ and $\mathrm{Pb}$ are concentrated in more coarse fractions, which are deposited closer to the emitting source, while $\mathrm{As}, \mathrm{Cd}$ and $\mathrm{Ni}$ could be found in finer fractions, which under the influence of wind can be spread over longer distances. For instance, higher concentrations of $\mathrm{Cu}$ and $\mathrm{Zn}$ in $\mathrm{PM}_{10}$ than in $\mathrm{PM}_{2.5}$ have been confirmed at a street location in Rotterdam, the Netherlands (Keuken et al. 2013). Additionally, more than 30 years of air quality control in Bor indicates consistently increased concentrations of $\mathrm{As}, \mathrm{Cu}, \mathrm{Cd}$ and $\mathrm{Zn}$, and periodically increased concentrations of $\mathrm{Pb}$ and $\mathrm{Ni}$, in ambient particulate and deposited matter (Dimitrijević et al. 2009; Serbula et al. 2012; Kovačević et al. 2010).

The content of HMs in parts of peach-trees sampled from eight sites is given in Fig. 2. However, while considering the obtained results, it should be kept in mind that all aboveground parts were analyzed as unwashed, so that the detected concentrations do not represent a real accumulation in these cases. The detected contents of HMs in peach parts decreased as follows: leaf $>$ root $>$ branch $>$ fruit. All values are compared with normal and critical values for plants/mature leaves in Table 3 .

Leaves accumulate HMs not only from soil but also from atmospheric deposition, and they can often be the best indicator of pollution. Extreme contents of $\mathrm{Cu}$ in all parts of peach (root $608 \mathrm{mg} / \mathrm{kg}$, branch $344 \mathrm{mg} / \mathrm{kg}$, leaf $306 \mathrm{mg}$ / $\mathrm{kg}$ and fruit $117 \mathrm{mg} / \mathrm{kg}$ ) are recorded only at site FJ, where soil is very acidic, with a very low content of OM and high EC. In a recently published work by Antonijević et al. 2012, the high concentrations of $\mathrm{Cu}$ in branches, leaves and fruit of peach-trees that grow on the dam of tailings pond have also been found. At several locations, the $\mathrm{Cu}$ concentration in leaves (BN $276 \mathrm{mg} / \mathrm{kg}$, SN $212.5 \mathrm{mg} / \mathrm{kg}$ and $\mathrm{S} 175 \mathrm{mg} / \mathrm{kg}$ ) was above the upper limit of toxic values in mature leaves (20-100 mg/kg, Table 3). Only at the control site $\mathrm{G}$, the $\mathrm{Cu}$ concentration of $13.37 \mathrm{mg} / \mathrm{kg}$ was within the normal range $(5-20 \mathrm{mg} / \mathrm{kg})$. Although $\mathrm{Cu}$ is an essential micronutrient for plant growth, it can also be phytotoxic at high concentrations. The excessive content of $\mathrm{Cu}$ can lead to inhibition of plant growth, lowering the biomass and root elongation (Francini and Sebastiani 2010, Weng et al. 2005; Xu et al. 2006). Despite the high concentration of $\mathrm{Cu}$, these symptoms were not observed in the studied peach-trees.

The $\mathrm{Zn}$ content in leaves is within normal values $(27-150 \mathrm{mg} / \mathrm{kg})$, at all sites. The $\mathrm{Pb}$ contents determined in leaves are at FJ $36 \mathrm{mg} / \mathrm{kg}$, BN $43.9 \mathrm{mg} / \mathrm{kg}$, NS $13.6 \mathrm{mg} / \mathrm{kg}$, SN $14.4 \mathrm{mg} / \mathrm{kg}$, O $8.58 \mathrm{mg} / \mathrm{kg}$, S $32.9 \mathrm{mg} / \mathrm{kg}$, D $13.7 \mathrm{mg} /$ $\mathrm{kg}$ and $\mathrm{G} 1.9 \mathrm{mg} / \mathrm{kg}$. These values are higher than the normal values in leaves $(5-10 \mathrm{mg} / \mathrm{kg}$ ), except for locations $\mathrm{O}$ and $\mathrm{G}$. At sites $\mathrm{FJ}$ and $\mathrm{BN}$, the $\mathrm{Pb}$ content is within the critical range for leaves $(30-300 \mathrm{mg} / \mathrm{kg})$. The toxic concentrations of As in leaves $(5-20 \mathrm{mg} / \mathrm{kg}$ ) are recorded at FJ $18.8 \mathrm{mg} / \mathrm{kg}$, BN $21.3 \mathrm{mg} / \mathrm{kg}$ and S $12.8 \mathrm{mg} / \mathrm{kg}$. At all other sites, As concentrations were above the normal range in leaves. The highest $\mathrm{Cd}$ concentrations in leaves were found at FJ $1.28 \mathrm{mg} / \mathrm{kg}, \mathrm{BN} 1.78 \mathrm{mg} / \mathrm{kg}$ and $\mathrm{S} 1.255 \mathrm{mg} / \mathrm{kg}$. At other sites, Cd concentration was less than $1 \mathrm{mg} / \mathrm{kg}$ but still above the normal range in leaves $(0.05-0.2 \mathrm{mg} / \mathrm{kg})$. The normal range of $\mathrm{Ni}$ in leaves is $0.1-5 \mathrm{mg} / \mathrm{kg}$. Only leaves from the sites FJ $5.44 \mathrm{mg} / \mathrm{kg}$ and $\mathrm{BN} 6.52 \mathrm{mg} / \mathrm{kg}$ were found to be far above this range. Compared with concentrations determined at site FJ (flotation tailing pond), some similar concentrations of $\mathrm{Pb}$ and $\mathrm{Cd}$ were found in a peachtrees on the reclaimed tailing dam in the manganese mine wasteland, China ( $\mathrm{Li}$ and Yang 2008).

With regard to the peach fruits, there is some risk associated with their consumption at all investigated sites, especially in the rural areas where unwashed fruits are often eaten. The recommendable maximum limits for HMs concentrations in fruit per net weight are $5 \mathrm{mg} / \mathrm{kg}$ for $\mathrm{Cu}$ and $\mathrm{Zn}$, $0.1 \mathrm{mg} / \mathrm{kg}$ for $\mathrm{Pb}$ and $0.05 \mathrm{mg} / \mathrm{kg}$ for Cd (EC no. 1881/2006; Matei et al. 2013). The Official Gazette of Republic of Serbia, no. 11/92 and 32/2002, recommends the following MAC in fruit: $\mathrm{Pb} 3$ (1), As 1 (0.1) and $\mathrm{Cd} 0.3(0.05) \mathrm{mg} / \mathrm{kg}$ d.w. (w.w). According to this, even at the control site, which is considered as an unpolluted location, the As content in unwashed fruit $(1.6 \mathrm{mg} / \mathrm{kg})$ is above the recommended limit. At other locations, concentrations of studied HMs in unwashed fruits are significantly higher than MACs in Serbia. It is 
Fig. 2 Heavy metal content in parts of peach-trees against studied sampling sites
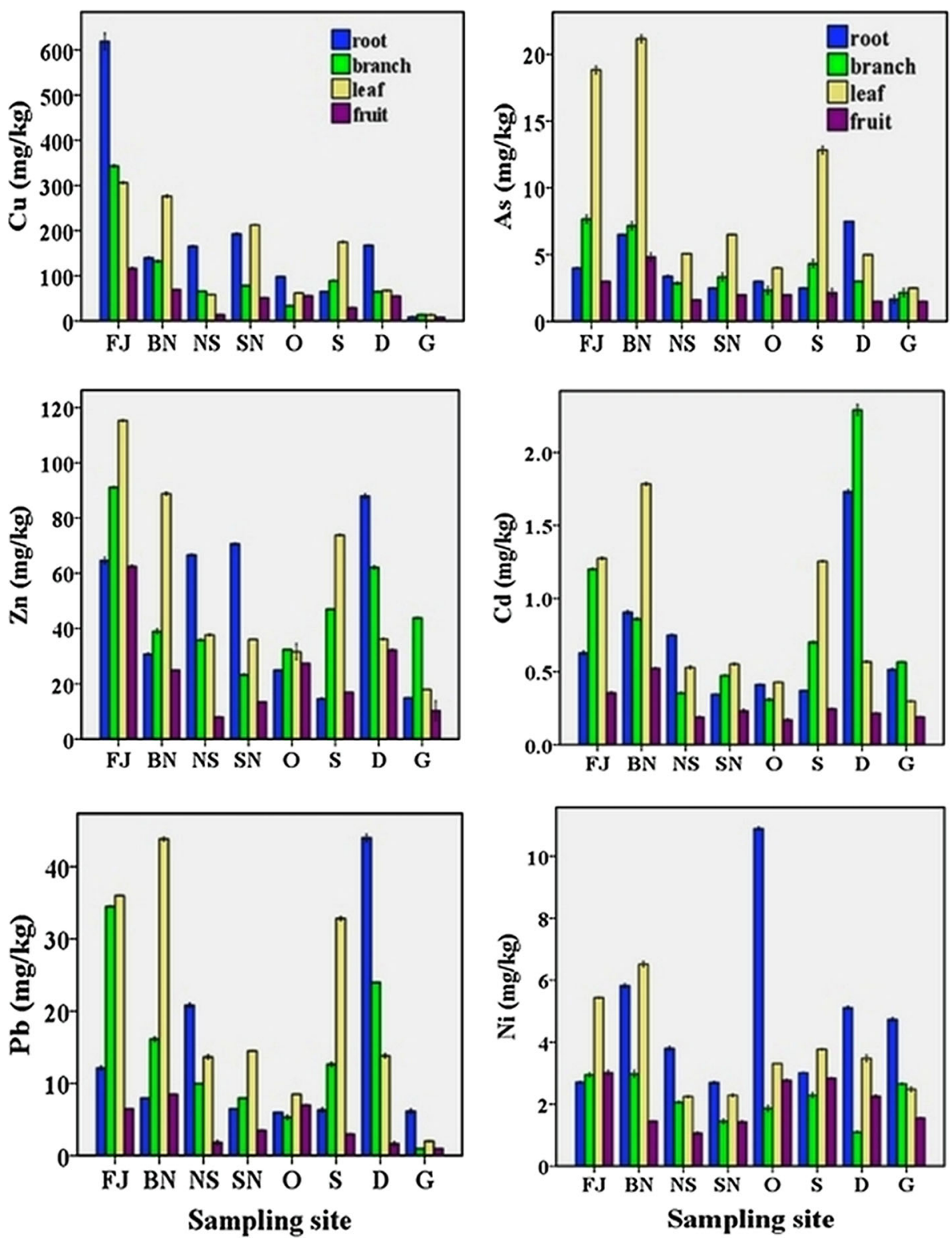

Table 3 Normal and toxic concentrations of heavy metals $(\mathrm{mg} / \mathrm{kg})$ in plants/mature leaves

\begin{tabular}{|c|c|c|c|c|c|c|}
\hline Heavy metal & $\mathrm{Cu}$ & $\mathrm{Zn}$ & $\mathrm{Pb}$ & As & $\mathrm{Cd}$ & $\mathrm{Ni}$ \\
\hline Normal range in plants ${ }^{\mathrm{a}}$ & $5-20$ & $1-400$ & $0.2-20$ & $0.02-7$ & $0.1-2.4$ & $0.02-5$ \\
\hline Sufficient or normal range in mature leaves ${ }^{b}$ & $5-30$ & $27-150$ & $5-10$ & $1-1.7$ & $0.05-0.2$ & $0.1-5$ \\
\hline Excessive or toxic concentrations in mature leaves ${ }^{\mathrm{a}, \mathrm{b}}$ & 20-100 & $100-400$ & $30-300$ & $5-20$ & $5-30$ & $10-100$ \\
\hline
\end{tabular}

${ }^{a}$ Agyarko et al. (2010)

b Kabata-Pendias (2011)

noteworthy that this kind of peach does not undergo any pesticide treatments. In an orchard, in Bursa (Turkey), which was irrigated using river water polluted by HMs, it was found that $\mathrm{Ni}$ and $\mathrm{Pb}$ were accumulated to the toxic levels in different parts of the fruit (pulp and peel) (Basar and Aydinalp
2005). At the same time, concentrations of HMs in the soil of the orchard were considerably lower than the ones given in this study. According to the record of the Environmental Working Group, peach is one of the most polluted fruits (Crinnion 2010). 


\section{Quantification of the level of pollution of soil and peach-tree parts}

\section{Soil enrichment}

The normalized element enrichment factors for soil from the studied sites, $\mathrm{EF}_{\text {soil }}$, are shown in Table 4. $\mathrm{EF}_{\text {soil }}$ between 0.5 and 2 could be considered as natural variability, while values higher than 2 indicate some enrichment corresponding mainly to the anthropogenic impact (Hernandez et al. 2003). According to this, the soil samples are not enriched with $\mathrm{Ni}$ and in some cases by $\mathrm{Zn}, \mathrm{Pb}$ and Cd (bolded values in Table 4). All soil samples are enriched by $\mathrm{Cu}$, and at six sites, there was an extremely high enrichment (86.42-101.46). $\mathrm{EF}_{\text {soil }}$ for $\mathrm{Zn}$ (1.53-7.47), $\mathrm{Pb}$ (1.05-7.47), As (2.15-13.42) and Cd (1.77-2.42) varied from moderate to significant levels. This indicates the anthropogenic influence on HM enrichment, i.e., the impact of smelting gases as a predominant source of pollution in the municipality of Bor.

\section{Enrichment of plant parts $\left(E F_{\text {plant }}\right)$}

High values of $\mathrm{EF}_{\text {plant }}$ (Table 5) indicate increased HMs concentration in parts of the peach-trees at the polluted sites. The highest enrichment by HMs was in the root and the leaf. At only two sites, FJ and D, the Pb enrichment was higher in branches. At site FJ, fruit was enriched by $\mathrm{Ni}$. Generally, values of $\mathrm{EF}_{\text {plant }}$ for all plant parts decreased as follows: $\mathrm{Cu}>\mathrm{Pb}>\mathrm{Zn}>\mathrm{As}>\mathrm{Cd}>\mathrm{Ni}$. Maximum values of $\mathrm{EF}_{\text {plant }}$ determined for specific HMs are as follows: $\mathrm{Cu}_{r / r}=68.80(\mathrm{FJ}), \mathrm{Zn}_{l / l}=6.45(\mathrm{FJ}), \mathrm{Pb}_{b / b}=30.97(\mathrm{FJ})$, $\mathrm{As}_{l / l}=9.05(\mathrm{BN}), \mathrm{Cd}_{l / l}=5.95(\mathrm{BN})$ and $\mathrm{Ni}_{f l f}=7.06(\mathrm{FJ})$.

\section{Biological concentration factor}

Biological concentration factor, BCF, shows a differing ability of the plant to accumulate or limit the accumulation of particulate metals from soil to the root. Calculated val-

Table 4 Element enrichment factors $\left(\mathrm{EF}_{\text {soil }}\right)$ for soil

\begin{tabular}{lrllrll}
\hline Site & \multicolumn{1}{l}{$\mathrm{Cu}$} & $\mathrm{Zn}$ & $\mathrm{Pb}$ & \multicolumn{1}{l}{$\mathrm{As}$} & $\mathrm{Cd}$ & $\mathrm{Ni}$ \\
\hline FJ & 90.96 & 4.53 & 3.00 & 8.56 & 2.13 & $\mathbf{0 . 5 4}$ \\
BN & 89.66 & 2.12 & 3.03 & 13.42 & 2.42 & $\mathbf{0 . 6 6}$ \\
NS & 101.46 & 4.80 & 6.91 & 10.46 & 2.03 & $\mathbf{1 . 3 0}$ \\
SN & 86.42 & 7.47 & 4.09 & 3.51 & 2.24 & $\mathbf{1 . 1 0}$ \\
O & 66.39 & 2.05 & 3.05 & 5.53 & $\mathbf{1 . 7 7}$ & $\mathbf{0 . 9 1}$ \\
S & 12.39 & $\mathbf{1 . 1 9}$ & $\mathbf{1 . 0 5}$ & 2.15 & $\mathbf{1 . 3 7}$ & $\mathbf{1 . 5 0}$ \\
D & 8.06 & $\mathbf{1 . 5 3}$ & $\mathbf{1 . 5 9}$ & 6.40 & $\mathbf{1 . 8 6}$ & $\mathbf{1 . 0 0}$ \\
\hline
\end{tabular}

Bold values-not enriched ues of BCF (Table 5) for the studied sites were less than 1, except for site $\mathrm{D}$ where an increased accumulation of $\mathrm{Cu}$ in the root was observed $(\mathrm{BCF}=1.187)$. Although at some sites, the uptake of HMs in the root of a peach-tree was relatively high, BCF values showed a tendency toward restricted soil-to-root transfer of HMs.

It can be said that the branched root of peach-trees can grow in the surface layers of the soil at a depth of 20-60 cm and can accumulate significant concentrations of HMs in its tissues. Therefore, the studied peach-tree could be applied for phytoremediation of shallow soils polluted with HMs. It is likely that the peach-tree will grow and develop even in tailings ponds covered with a very thin layer of humus. However, it should be kept in mind that the fruits from the trees planted for phytoremediation purposes are not safe for consumption. Namely, it is obvious from the obtained results that peach-tree fruits are susceptible to the retention of airborne particulate matter with high contents of HMs.

\section{Ratios of heavy metal concentrations between plant parts}

As explained above, the aboveground parts of peach-trees were not washed in order to assess the direct effect of atmospheric pollution (Oliva and Mingorance 2006). Table 6 shows the mean values of the three ratios $(R)$ for six HMs, at all sampling sites. $R_{1 / b}$ for all examined sites, except for the control one, are higher than $1, R_{f l l}$ are less than 1 , while $R_{f / b}$ is higher than 1 only at site O. The highest value for $R_{l / b}$ was determined at sites $\mathrm{BN}=2.38$ and $\mathrm{S}=2.09$, while the lowest value was determined at the controlling site $G=0.94$. This situation is not unexpected because the sites $\mathrm{BN}$ and $\mathrm{S}$ are in the direction of predominant winds, which transfer the pollutants emitted from the copper smelter smokestacks. Additionally, as a simple consequence of the closeness to the smokestacks, site $\mathrm{BN}$ is constantly exposed to severe contamination. These results demonstrate that the level of contamination of peach-tree leaves corresponds to the level of atmospheric pollution. The results show that the leaves of deciduous trees such as peach-trees may also be a good indicator of atmospheric pollution in areas that lack evergreen trees, well known as an excellent indicator of pollution (Oliva and Mingorance 2006).

\section{Statistical analysis}

Relationship between concentration of HMs in soil, physical and chemical parameters of soil and distance from the source of pollution are evaluated by Pearson's correlation coefficients given in Table 7 . 
Table 5 Element enrichment factors for peach-tree parts $\left(\mathrm{EF}_{\text {plant }}\right)$ and biological concentration factors $(\mathrm{BCF})$

\begin{tabular}{|c|c|c|c|c|c|c|c|}
\hline Sampling site & $\mathrm{EF}_{\text {plant }}$ & $\mathrm{Cu}$ & $\mathrm{Zn}$ & $\mathrm{Pb}$ & As & $\mathrm{Cd}$ & $\mathrm{Ni}$ \\
\hline \multirow[t]{4}{*}{ FJ } & $r / r$ & 68.80 & 4.32 & 1.93 & 2.38 & 1.21 & 0.57 \\
\hline & $b / b$ & 24.81 & 2.07 & 30.97 & 3.49 & 2.11 & 1.11 \\
\hline & $l / l$ & 22.91 & 6.45 & 18.98 & 8.02 & 4.25 & 2.19 \\
\hline & $f / f$ & 13.71 & 6.20 & 6.93 & 1.82 & 1.87 & 7.06 \\
\hline $\mathrm{BCF}$ & & 0.444 & 0.202 & 0.111 & 0.113 & 0.144 & 0.184 \\
\hline \multirow[t]{4}{*}{$\mathrm{BN}$} & $r / r$ & 15.83 & 2.05 & 1.28 & 3.69 & 1.74 & 1.23 \\
\hline & $b / b$ & 9.58 & 0.88 & 14.43 & 3.29 & 1.51 & 1.12 \\
\hline & $l / l$ & 20.68 & 4.96 & 23.09 & 9.05 & 5.95 & 2.63 \\
\hline & $f / f$ & 8.20 & 2.47 & 9.05 & 3.00 & 2.76 & 0.93 \\
\hline $\mathrm{BCF}$ & & 0.088 & 0.173 & 0.063 & 0.095 & 0.154 & 0.273 \\
\hline \multirow[t]{4}{*}{ NS } & $r / r$ & 18.73 & 4.44 & 3.33 & 1.95 & 1.44 & 0.80 \\
\hline & $b / b$ & 4.75 & 0.81 & 9.14 & 1.31 & 0.62 & 0.78 \\
\hline & $l / l$ & 4.39 & 2.11 & 7.18 & 2.16 & 1.77 & 0.91 \\
\hline & $f / f$ & 1.62 & 0.81 & 1.86 & 1.01 & 1.00 & 0.69 \\
\hline $\mathrm{BCF}$ & & 0.113 & 0.203 & 0.088 & 0.079 & 0.187 & 0.111 \\
\hline \multirow[t]{4}{*}{$\mathrm{SN}$} & $r / r$ & 21.84 & 4.71 & 1.03 & 1.38 & 0.66 & 0.57 \\
\hline & $b / b$ & 5.67 & 0.53 & 7.14 & 1.50 & 0.83 & 0.55 \\
\hline & $l / l$ & 15.89 & 2.01 & 7.57 & 2.72 & 1.85 & 0.92 \\
\hline & $f / f$ & 6.05 & 1.33 & 3.72 & 1.24 & 1.24 & 0.92 \\
\hline $\mathrm{BCF}$ & & 0.169 & 0.152 & 0.049 & 0.182 & 0.086 & 0.102 \\
\hline \multirow[t]{4}{*}{$\mathrm{O}$} & $r / r$ & 11.10 & 1.68 & 0.98 & 1.82 & 0.80 & 2.30 \\
\hline & $b / b$ & 2.42 & 0.73 & 4.76 & 1.02 & 0.54 & 0.71 \\
\hline & $l / l$ & 4.62 & 1.77 & 4.52 & 1.74 & 1.42 & 1.34 \\
\hline & $f l f$ & 6.55 & 2.72 & 7.29 & 1.13 & 0.89 & 1.78 \\
\hline $\mathrm{BCF}$ & & 0.099 & 0.173 & 0.056 & 0.135 & 0.115 & 0.441 \\
\hline \multirow[t]{4}{*}{ S } & $r / r$ & 7.41 & 0.97 & 1.00 & 1.46 & 0.71 & 0.64 \\
\hline & $b / b$ & 6.43 & 1.07 & 11.41 & 1.94 & 1.24 & 0.86 \\
\hline & $l / l$ & 13.08 & 4.12 & 17.33 & 5.43 & 4.18 & 1.52 \\
\hline & $f / f$ & 3.45 & 1.70 & 3.29 & 1.38 & 1.29 & 1.82 \\
\hline BCF & & 0.318 & 0.156 & 0.150 & 0.250 & 0.119 & 0.066 \\
\hline \multirow[t]{4}{*}{ D } & $r / r$ & 18.96 & 5.87 & 7.00 & 4.27 & 3.34 & 1.08 \\
\hline & $b / b$ & 4.71 & 1.41 & 21.71 & 1.44 & 4.03 & 0.41 \\
\hline & $l / l$ & 5.07 & 2.02 & 7.20 & 2.10 & 1.90 & 1.40 \\
\hline & $f l f$ & 6.57 & 3.19 & 1.81 & 0.94 & 1.13 & 1.45 \\
\hline BCF & & 1.187 & 0.693 & 0.659 & 0.231 & 0.391 & 0.160 \\
\hline G BCF & & 0.961 & 0.345 & 0.285 & 0.664 & 0.414 & 0.282 \\
\hline
\end{tabular}

$r$ root, $b$ branch, $l$ leaf, $f$ fruit
Table 6 Mean values of the three ratios $(R)$ for all HMs at studied sampling sites

\begin{tabular}{lllllllll}
\hline Ratio (R) & \multicolumn{9}{l}{ Sampling site } \\
\cline { 2 - 9 } & FJ & BN & NS & SN & O & S & D & G \\
\hline $\mathrm{R}_{\mathrm{l} / \mathrm{b}}$ & 1.43 & 2.38 & 1.27 & 1.79 & 1.57 & 2.09 & 1.20 & 0.94 \\
$\mathrm{R}_{\mathrm{f} / 1}$ & 0.35 & 0.29 & 0.29 & 0.37 & 0.71 & 0.27 & 0.53 & 0.67 \\
$\mathrm{R}_{\mathrm{f} / \mathrm{b}}$ & 0.48 & 0.58 & 0.37 & 0.61 & 1.11 & 0.51 & 0.68 & 0.56 \\
\hline
\end{tabular}

$l$ leaf, $b$ branch, $f$ fruit
A large number of metal pairs such as $\mathrm{Cu}-\mathrm{Zn}, \mathrm{Cu}-\mathrm{Pb}$, $\mathrm{Cu}-\mathrm{As}, \mathrm{Cu}-\mathrm{Cd}, \mathrm{Zn}-\mathrm{Pb}, \mathrm{Zn}-\mathrm{Cd}, \mathrm{Pb}-\mathrm{As}, \mathrm{Pb}-\mathrm{Cd}$ and $\mathrm{As}-\mathrm{Cd}$ showed a significant positive correlation in soil $(r=0.684), \quad(r=0.813), \quad(r=0.716), \quad(r=0.692)$, $(r=0.677),(r=0.411),(r=0.573),(r=0.504)$ and $(r=0.862)$, respectively. Very strong and positive correlations were found between $\mathrm{Cd}$ and $\mathrm{As}$. In the case of all HMs (with the exception of $\mathrm{Ni}$ ), a significant negative correlation with respect to the distance is observed. This indicates that the concentration of HMs decreases with the 


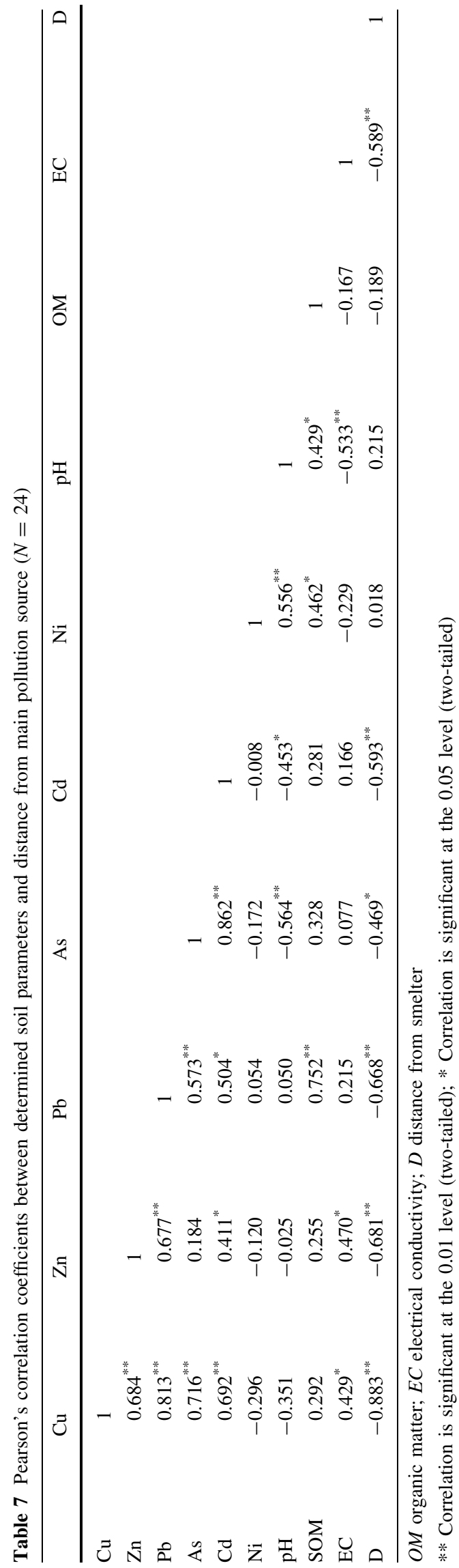

distances from the source of pollution. Moreover, a very weak correlation is observed in the case of $\mathrm{Ni}$. It means that $\mathrm{Ni}$ does not originate from the same anthropogenic source of pollution; it is more likely that $\mathrm{Ni}$ is of a geological origin (Alagić et al. 2015). A significant correlation was found between $\mathrm{As}, \mathrm{Cd}$ and $\mathrm{Ni}$ content and $\mathrm{pH}$ of the soil, while $\mathrm{Pb}$ and $\mathrm{Ni}$ significantly correlated with $\mathrm{OM}$.

Correlations between HMs in peach-tree parts are given in Table 8. A significant number of metal pairs show positive and very strong correlations as it is observed in soil. The highest number of these correlations is determined between certain $\mathrm{HMs}$ in leaves: $\mathrm{PbL}-\mathrm{ZnL}$ $(r=0.927)$, AsL-ZnL $(r=0.950)$, AsL-PbL $(r=0.976)$, $\mathrm{CdL}-\mathrm{PbL}(r=0.987)$, CdL-AsL $(r=0.972)$ and NiLAsL $(r=0.921)$. Additionally, all HMs in leaves show excellent correlations with As in branches. Correlations of As and $\mathrm{Cd}$ in the fruit with $\mathrm{Zn}, \mathrm{Pb}, \mathrm{As}$ and $\mathrm{Cd}$ in the leaves are also significant. The least significant correlation is between $\mathrm{NiR}, \mathrm{NiB}, \mathrm{PbF}$ and $\mathrm{NiF}$ and $\mathrm{HMs}$ in plant parts.

Table 9 displays some additional significant correlations. Significant negative correlations are found between $\mathrm{pH}$ and the content of HMs in peach-tree parts, with the exception of $\mathrm{Zn}, \mathrm{Pb}, \mathrm{Cd}$ and $\mathrm{Ni}$, in the root and $\mathrm{Ni}$ in the fruit. Significant positive correlations are found for $\mathrm{Cu}$, $\mathrm{As}$ and $\mathrm{Cd}$ in the soil relative to HMs content in leaves and fruit, with the exception of $\mathrm{Zn}$ and $\mathrm{Ni}$ in the fruit. Additionally, a larger number of positive correlations are observed between EC and HM in peach-tree parts, as well as a higher number of negative correlations relative to the distance from the source of pollution.

Principal component analysis (PCA) was performed using the varimax rotation and Kaiser criterion (eigenvalues $>1$ ) and taking into consideration the loading coefficients $\geq 0.40$. The loadings having a value greater than 0.71 (typically regarded as excellent, Garcia et al. 2004) are marked bold in Table 10 .

It was obvious from PCA results that the first four of the six principal components extracted explained the $86.3 \%$ of the total variance (Table 10). PCA1-PCA4 are related to the contents of HMs in soil, roots and aboveground parts of peach. PCA1 accounts for $45.8 \%$ of the total variance, while heaving high loadings in leaves indicates high influence of atmospheric deposition on this plant part. PCA2, PCA3 and PCA4 explain 17.5, 12.6 and 10.5\%, respectively, of the total variance with high loadings in branches, roots and soil. It can be said that first four principal components PCA1-PCA4 explain the contribution of metals from local anthropogenic activities (copper smelting). PCA5 and PCA6 correlated strongly only with $\mathrm{Ni}$. Loading of -0.900 for $\mathrm{Ni}$ in soil suggests that the principal source of this metal is dissimilar regarding other metals, i.e., is lithogenic. 


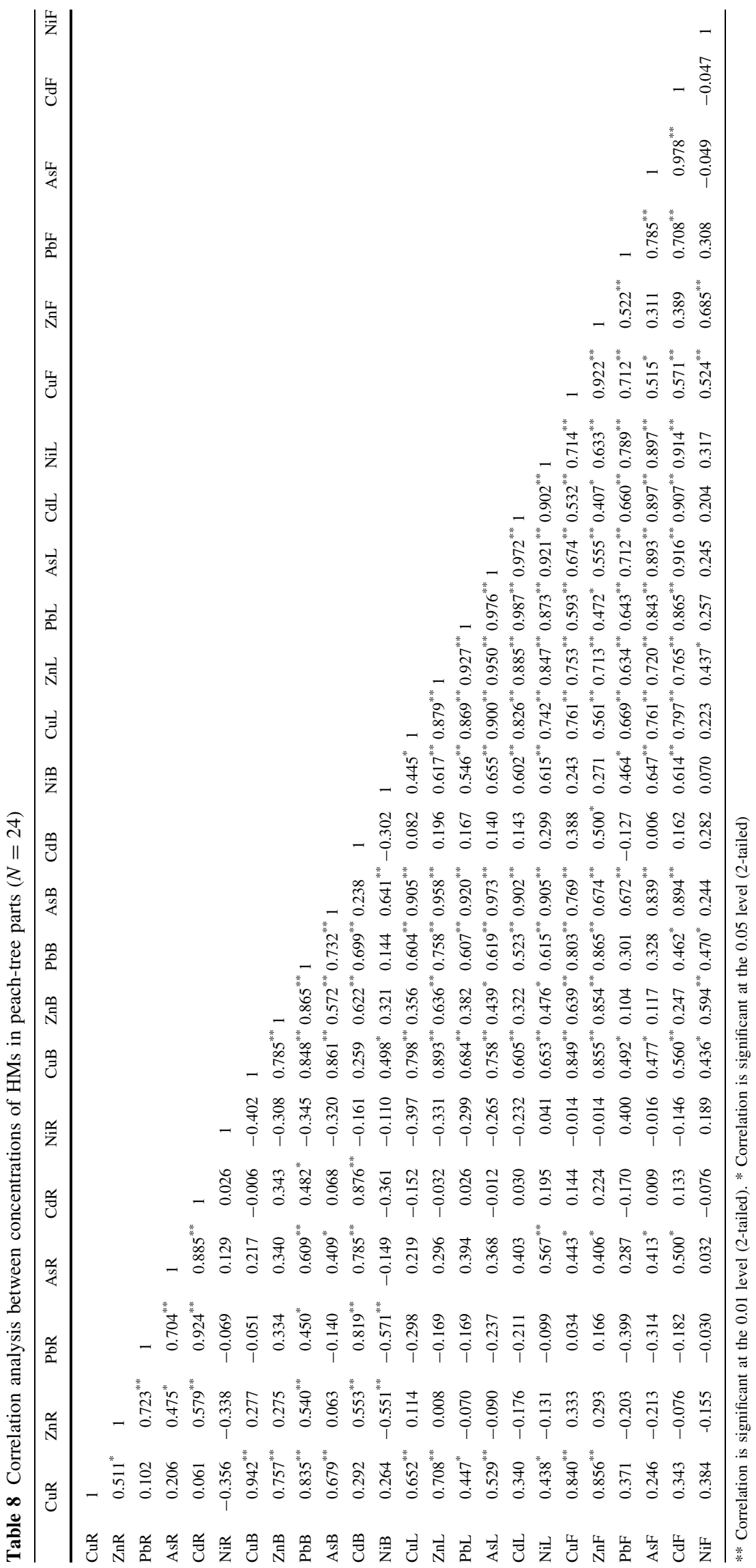




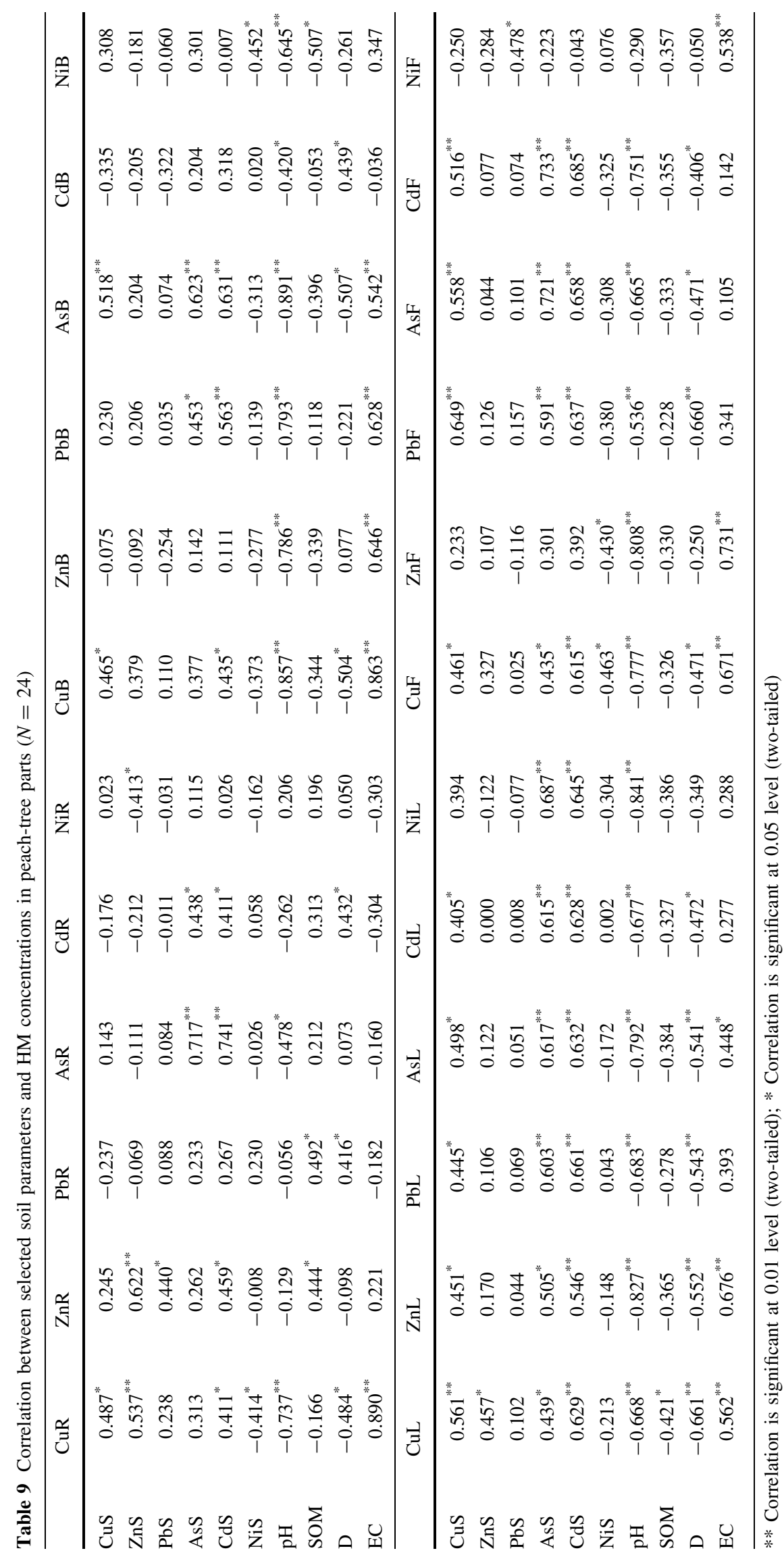


Table 10 PCA factors and loadings for heavy metals contents (mg/kg/, d.w.) in soil and parts of peach-tree

\begin{tabular}{|c|c|c|c|c|c|c|c|}
\hline Variables & PCA 1 & PCA 2 & PCA 3 & PCA 4 & PCA 5 & PCA 6 & Communality \\
\hline $\mathrm{Cu}$ root & & 0.856 & & & & & 0.994 \\
\hline $\mathrm{Zn}$ root & & & 0.630 & 0.598 & & & 0.984 \\
\hline $\mathrm{Pb}$ root & & & 0.938 & & & & 0.983 \\
\hline As root & 0.401 & & 0.881 & & & & 0.997 \\
\hline $\mathrm{Cd}$ root & & & 0.997 & & & & 0.999 \\
\hline Ni root & & & & & 0.960 & & 0.991 \\
\hline $\mathrm{Cu}$ branch & 0.494 & 0.797 & & & & & 0.991 \\
\hline Zn branch & & 0.805 & & & & & 0.942 \\
\hline $\mathrm{Pb}$ branch & & 0.755 & 0.480 & & & & 0.991 \\
\hline As branch & 0.858 & 0.460 & & & & & 0.999 \\
\hline Cd branch & & & 0.868 & & & & 0.975 \\
\hline Ni branch & 0.650 & & -0.451 & & & 0.492 & 0.902 \\
\hline $\mathrm{Cu}$ leaf & 0.764 & 0.462 & & & & & 0.921 \\
\hline Zn leaf & 0.795 & 0.571 & & & & & 0.983 \\
\hline $\mathrm{Pb}$ leaf & 0.935 & & & & & & 0.999 \\
\hline As leaf & 0.938 & & & & & & 1.000 \\
\hline Cd leaf & 0.975 & & & & & & 1.000 \\
\hline Ni leaf & 0.895 & & & & & & 0.999 \\
\hline $\mathrm{Cu}$ fruit & 0.443 & 0.800 & & & & & 0.960 \\
\hline Zn fruit & & 0.908 & & & & & 0.996 \\
\hline $\mathrm{Pb}$ fruit & 0.683 & & & & 0.592 & & 0.990 \\
\hline As fruit & 0.957 & & & & & & 0.981 \\
\hline $\mathrm{Cd}$ fruit & 0.949 & & & & & & 0.973 \\
\hline $\mathrm{Ni}$ fruit & & 0.765 & & -0.440 & & & 0.990 \\
\hline $\mathrm{Cu}$ soil & 0.457 & & & 0.823 & & & 0.980 \\
\hline Zn soil & & & & 0.898 & & & 0.954 \\
\hline $\mathrm{Pb}$ soil & & & & 0.904 & & & 0.850 \\
\hline As soil & 0.680 & & 0.437 & 0.447 & & & 0.939 \\
\hline Cd soil & 0.626 & & 0.439 & 0.554 & & & 0.992 \\
\hline Ni soil & & & & & & -0.900 & 0.944 \\
\hline Eigenvalue & 13.73 & 5.26 & 3.78 & 3.14 & 1.98 & 1.31 & \\
\hline Variance $(\%)$ & 45.76 & 17.53 & 12.59 & 10.46 & 6.60 & 4.38 & \\
\hline Cumulative (\%) & 45.76 & 63.29 & 75.88 & 86.34 & 92.94 & 97.32 & \\
\hline
\end{tabular}

Variables with loadings $\geq 0.70$ were identified as significant variables and they are in bold
The structure of relations among the contents of HMs in soil and parts of peach-tree is illustrated in three-dimensional (3D) space (Fig. 3).

PCA revealed a strong correlation between the contents of heavy metals, especially in the aboveground parts of the peach-tree, as can be seen in Fig. 3 where the largest grouping exists in the case of variables related to the aboveground parts.

\section{Conclusion}

Results of the present study revealed that the copper smelter activity brings to soil pollution by $\mathrm{Cu}, \mathrm{Zn}, \mathrm{Pb}, \mathrm{As}$, $\mathrm{Cd}$, as follows: UI areas were more polluted than the rural ones by $\mathrm{Cu}, \mathrm{Zn}$ and $\mathrm{Pb}$, while for $\mathrm{As}$ and $\mathrm{Cd}$, this was not observed; the soil in UI areas was extremely polluted by $\mathrm{Cu}$; the soil pollution by HMs followed a trend: 


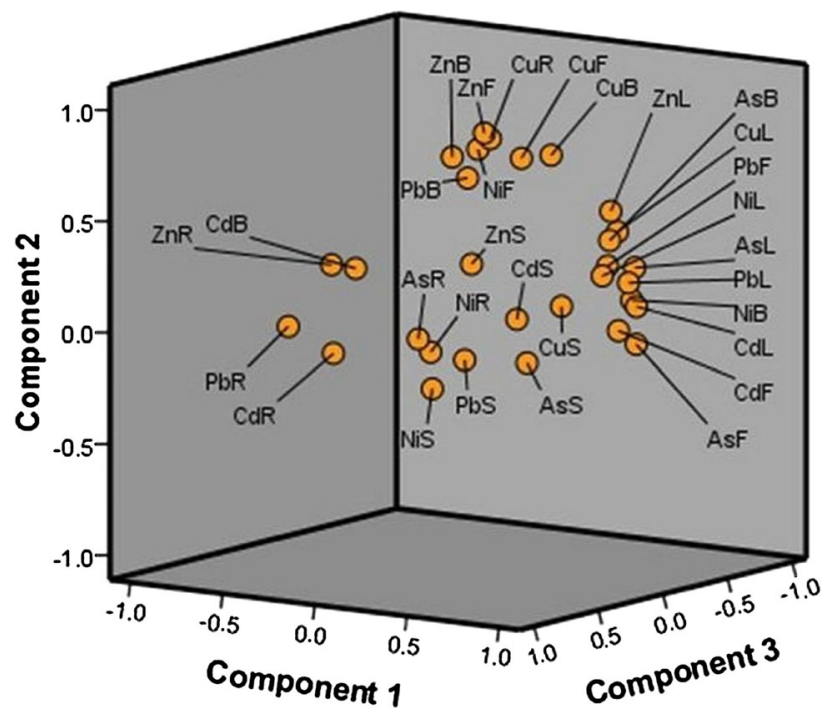

Fig. 3 PCA 3D plot for HM contents in soil and parts of peach-tree

$\mathrm{Cu}>\mathrm{As}>\mathrm{Zn}>\mathrm{Pb}>\mathrm{Cd}$. Computed $\mathrm{EF}_{\text {soil }}$ also showed that the soil was enriched by the mentioned HMs (except $\mathrm{Ni}$ ). The highest enrichment was by $\mathrm{Cu}$. For the examined HMs (except Ni), significant negative correlations in relation to the distance from the pollution source were determined which means that pollution from the RTB Bor metallurgical complex decreased with increasing distance from the smelter. The concentrations of HMs in many plant parts of peach-trees were above the normal ones, that is, at the levels of phytotoxicity, and the highest contents were determined for $\mathrm{Cu}$. $\mathrm{EF}_{\text {plant }}$ showed that the highest metal enrichment was in the root and the leaf of peach-trees close to the smelter. On the other hand, the low values of BCF indicated the peach's tendency to restrict massive transfer of HMs from soil to the root. The results obtained from statistical analysis (Pearson correlation analysis and PCA) confirmed that the contents of HMs in the aboveground plant parts originated mainly from the atmosphere, i.e., from the copper smelter. The content of $\mathrm{Ni}$ in the soil is demonstrated to be of geogenic origin. The three ratios $\left(R_{l l}\right.$ ${ }_{b}, R_{f l l}$ and $R_{f / b}$ ) demonstrated that the leaves were the best indicators of pollution by atmospheric deposition. This was additionally confirmed by high positive correlations between metals in the leaves. At all examined sites, the concentrations of HMs in the fruit of the peach-trees were above the allowed limits so that the fruits were not safe for consumption. Even at the controlled location G, $19 \mathrm{~km}$ away from the copper smelter, an increased content of As in fruits was found.
It can be concluded that the peach-tree $P$. persica $\mathrm{L}$. Batech may be classified as a metallophyte since it can grow in soils with high concentrations of HMs that are toxic for most of the other plants. It is demonstrated that peach-trees are tolerant to extremely high concentrations of $\mathrm{Cu}$ when the concentrations of other HMs are also high. Therefore, the studied peach-tree can be considered as a potential plant for phytoremediation, in particular for phytostabilization of soil that is contaminated by various HMs. Additionally, analysis of peach-tree leaves revealed their potential to be used as an excellent biomonitor for atmospheric pollution in industrial zones.

Acknowledgments Authors are grateful to the Ministry of Education, Science and Technological Development of Serbia for financial support (Project No. 172031).

\section{References}

Agyarko K, Darteh E, Berlinger B (2010) Metal levels in some refuse dump soils and plants in Ghana. Plant Soil Environ 56:244-251

Alagić SČ, Šerbula SS, Tošić SB, Pavlović AN, Petrović JV (2013) Bioaccumulation of arsenic and cadmium in birch and lime from the Bor region. Arch Environ ContamToxicol 65:671-682

Alagić SČ, Tošić SB, Dimitrijević MD, Antonijević MM, Nujkić MM (2015) Assessment of the quality of polluted areas based on the content of heavy metals in different organs of the grapevine (Vitis vinifera) cv. Tamjanika. Environ Sci Pollut Res 22(9):7155-7175

Alloway B (2013) Heavy metals in soils: trace metals and metalloids in soils and their bioavailability. Environmental Pollution, vol 22, 3rd edn. Springer, Berlin

Alvarez E, Fernandez Marcos ML, Vaamonde C, Fernandez-Sanjurjo MJ (2003) Heavy metals in the dump of an abandoned mine in Galicia (NW Spain) and in the spontaneously occurring vegetation. Sci Total Environ 313:185-197

Anju M, Banerjee DK (2012) Multivariate statistical analysis of heavy metals in soils of a $\mathrm{Pb}-\mathrm{Zn}$ mining area, India. Environ Monit Assess 184:4191-4206

Antonijević MM, Dimitrijević MD, Stevanović ZO, Šerbula SM, Bogdanović GD (2008) Investigation of the possibility of copper recovery from the flotation tailings by acid leaching. $J$ Hazard Mater 158:23-34

Antonijević MM, Dimitrijević MD, Milić SM, Nujkić MM (2012) Metal concentrations in the soils and native plants surrounding the old flotation tailings pond of the Copper Mining and Smelting Complex Bor (Serbia). J Environ Monit 14:866-877

Arnetoli M, Vooijs R, Gonnelli C, Gabbrielli R, Verkleij JAC, Schat $\mathrm{H}$ (2008) High-level $\mathrm{Zn}$ and Cd tolerance in Silene paradoxa $\mathrm{L}$. from a moderately $\mathrm{Cd}$ - and $\mathrm{Zn}$-contaminated copper mine tailing. Environ Pollut 156:380-386

Ashraf MA, Maah MJ, Yusoff I (2011) Heavy metals accumulation in plants growing in ex tin mining catchment. Int $\mathrm{J}$ Environ Sci Technol 8:401-416 
Ayari F, Hamdi H, Jedidi N, Gharbi N, Kossai R (2010) Heavy metal distribution in soil and plant in municipal solid waste compost amended plots. Int J Environ Sci Technol 7:465-472

Balabanova B, Stafilov T, Šajn R, Baèeva K (2012) Characterisation of heavy metals in lichen species Hypogymnia Physodes and Evernia Prunastri due to biomonitoring of air pollution in the vicinity of copper mine. Int J Environ Res 6(3):779-794

Basar H, Aydinalp C (2005) Heavy metal contamination in peach trees irrigated with water from a heavily polluted creek. J Plant Nutr 28:2049-2063

Bianchini F, Pascali G, Campo A, Orecchio S, Bonsignore R, Blandino P, Pietrini P (2015) Elemental contamination of an open-pit mining area in the Peruvian Andes. Int $\mathrm{J}$ Environ Sci Technol 12(3):1065-1074

Chojnacka K, Chojnacki A, Górecka H, Górecki H (2005) Bioavailability of heavy metals from polluted soils to plants. Sci Total Environ 337:175-182

Commission Regulation (EC) No. 1881/2006 of 19 December (2006) Setting maximum levels for certain contaminants in food stuffs

Crinnion JW (2010) Organic foods contain higher levels of certain nutrients, lower levels of pesticides, and may provide health benefits for the consumer. Altern Med Rev 15:4-12

Dimitrijević M, Kostov A, Tasić V, Milošević N (2009) Influence of pyrometallurgical copper production on the environment. J Hazard Mater 164:892-899

Doležalová Weissmannová H, Pavlovský J, Chovanec P (2015) Heavy metal contaminations of urban soils in Ostrava, Czech Republic: assessment of metal pollution and using principal component analysis. Int J Environ Res 9(2):683-696

Francini A, Sebastiani L (2010) Copper effects on Prunus persica in two different grafting combinations $(P$. persica $\times P$. amygdalus and $P$. cerasifera). J Plant Nutr 33:1338-1352

Garcia JH, Li WW, Arimoto R, Okrasinski R, Greenlee J, Walton J, Schloesslin C, Sage S (2004) Characterization and implication of potential fugative dust sources in the Paso del Norte region. Sci Total Environ 325:95-112

Gonzalez RC, Gonzalez-Chavez MCA (2006) Metal accumulation in wild plants surrounding mining wastes. Environ Pollut 144:84-92

Hernandez L, Probst A, Probst JL, Ulrich E (2003) Heavy metal distribution in some French forest soils: evidence for atmospheric contamination. Sci Total Environ 312:195-219

Jolivet C, Arrouays D, Bernoux M (1998) Comparison between analytical methods for organic carbon and organic matter determination in sandy Spodosols of France. Commun Soil Sci Plant Anal 29:2227-2233

Kabata-Pendias A (2011) Trace elements in soils and plants, 4th edn. CRC Press, Boca Raton

Kabata-Pendias A, Mukherjee AB (2007) Trace elements from soil to human. Springer, Berlin

Keuken MP, Moerman M, Voogt M, Blom M, Weijers EP, Röckmann T, Dusek U (2013) Source contributions to $\mathrm{PM}_{2.5}$ and $\mathrm{PM}_{10}$ at an urban background and a street location. Atmos Environ $71: 26-35$

Kisku GC, Barman SC, Bhargava SK (2000) Contamination of soil and plants with potentially toxic elements irrigated with mixed industrial effluent and its impact on the environment. Water Air Soil Pollut 120:121-137

Kovačević R, Jovašević-Stojanović $M$, Tasić $V$, Milošević $N$, Petrović N, Stanković S, Matić-Besarabić S (2010) Preliminary analysis of levels of arsenic and other metalic elements in $\mathrm{PM}_{10}$ sampled near Copper smelter Bor (Serbia). CI\&CEQ 16(3):269-279

Li MS, Yang SX (2008) Heavy metal contamination in soils and phytoaccumulation in a manganese mine wasteland, South China. Air Soil Water Res 1:31-41

Li Y, Wang YB, Gou X, Su YB, Wang G (2006) Risk assessment of heavy metals in soils and vegetables around non-ferrous metals mining and smelting sites, Baiyin, China. J Environ Sci 18:1124-1134

Local Environmental Action Plan (LEAP) Bor (2003) Municipality Bor

Malmstrom ME, Gleisner M, Herbert RB (2006) Element discharge from pyritic mine tailings at limited oxygen availability in column experiments. Appl Geochem 21:184-202

Matei N, Popescu A, Munteanu M, Lucian Radu G (2013) The assessment of $\mathrm{Cd}, \mathrm{Zn}, \mathrm{Pb}, \mathrm{Cu}$ and vitamin $\mathrm{C}$ in peaches. UPB Sci Bull Series B 75:73-80

Mehes-Smith M, Nkongolo KK, Narendrula R, Cholewa E (2013) Mobility of heavy metals in plants and soil: a case study from a mining region in Canada. Am J Environ Sci 9:483-493

Mingorance MD, Valdés B, Oliva SR (2007) Strategies of heavy metal uptake by plants growing under industrial emissions. Environ Int 33:514-520

Moore JN, Louma SN (1990) Hazardous wastes from large-scale metal extraction. Environ Sci Technol 24:1278-1285

Mudgal V, Madaan N, Mudgal A (2010) Heavy metals in plants: phytoremediation: plants used to remediate heavy metal pollution. Agric Biol J N Am 1:40-46

Nagajyoti PC, Lee KD, Sreekanth TVM (2010) Heavy metals, occurrence and toxicity for plants: a review. Environ Chem Lett 8:199-216

Oliva SR, Espinosa AJF (2007) Monitoring of heavy metals in topsoils, atmospheric particles and plant leaves to identify possible contamination sources. Microchem J 86:131-139

Oliva SR, Mingorance MD (2006) Assessment of airborne heavy metal pollution by aboveground plant parts. Chemosphere 65:177-182

Radwan MA, Salama AK (2006) Market basket survey for some heavy metals in Egyptian fruits and vegetables. Food ChemToxicol 44:1273-1278

Rashed MN (2010) Monitoring of contaminated toxic and heavy metals, from mine tailings through age accumulation, in soil and some wild plants at Southeast Egypt. J Hazard Mater 178:739-746

Saba G, Parizanganeh AH, Zamani A, Saba J (2015) PhytoremeDiation of heavy metals contaminated environments: screening for native accumulator plants in Zanjan-Iran. Int $\mathbf{J}$ Environ Res 9(1):309-316

Sadhu K, Adhikari K, Gangopadhyay A (2012) Effect of mine spoil on native soil of Lower Gondwana coal fields: Raniganj coal mines areas, India. Inter J Environ Sci 2:1675-1687

Salvagio Manta D, Angelone M, Bellanca A, Neri R, Sprovieri M (2002) Heavy metals in urban soils: a case study from the city of Palermo (Sicily), Italy. Sci Total Environ 300:229-243

Serbula SM, Miljkovic DDJ, Kovacevic RM, Ilic AA (2012) Assessment of airborne heavy metal pollution using plant parts and topsoil. Ecotox Environ Safe 76:209-214

Stüben D, Berner Z, Kappes B, Puchelt H (2001) Environmental monitoring of heavy metals and arsenic from $\mathrm{Ag}-\mathrm{Pb}-\mathrm{Zn}$ mining, a case study over two Millennia. Environ Monit Assess 70:181-200 
Sutherland RA (2000) Bed sediment-associated trace metals in an urban stream, Oahu, Hawaii. Environ Geol 39:611-627

The Official Gazette of Republic of Serbia, no. 88/2010: the decree on the soil quality monitoring programme using indicators for assessing the risks from the soil degradation as well as the methodology for working out the remediation programme

Tian D, Zhu F, Yan W, Fang X, Xiang W, Deng X, Wang G, Peng C (2009) Heavy metal accumulation by panicled goldenrain tree (Koelreuteria paniculata) and common elaeocarpus (Elaeocarpus decipiens) in abandoned mine soils in southern China. J Environ Sci China 21:340-345
Weng G, Wu L, Wang Z, Luo Y, Christie P (2005) Copper uptake by four Elsholtzia ecotypes supplied with varying levels of copper in solution culture. Environ Int 31:880-884

Xu J, Yang L, Wang Z, Dong G, Huang J, Wang Y (2006) Toxicity of copper on rice growth and accumulation of copper in rice grain in copper contaminated soil. Chemosphere 62:602-607

US EPA METHOD 3052: Microwave assisted acid digestion of siliceous and organically based matrices 